\title{
Control of Platinum Loss in WEEE Smelting
}

\author{
LASSI KLEMETTINEN (10, ${ }^{1}$ KATRI AVARMAA (iD, ${ }^{1}$ HUGH O'BRIEN (iD, ${ }^{2}$ \\ ARI JOKILAAKSO (10, ${ }^{1}$ and PEKKA TASKINEN (i) ${ }^{1,3}$
}

\begin{abstract}
1.-Department of Chemical and Metallurgical Engineering, School of Chemical Engineering, Aalto University, P.O. Box 16100, 00076 Aalto, Finland. 2.-Geological Survey of Finland, Vuorimiehentie 2, 02150 Espoo, Finland. 3.—e-mail: pekka.taskinen@aalto.fi
\end{abstract}

In spite of significant economic value, the solubilities of the platinum group and precious metals in metallurgical copper smelting slags are not well known. Recent experimental information on iron-free and low-iron silicate melts indicates that the chemical solubility of platinum is very low, $<1 \mathrm{ppmw}$ (part per million weight). In this study, the concentration of platinum in alumina spinel-saturated iron silicate slags in equilibrium with a solid ironplatinum alloy was measured as a function of oxygen partial pressure at $1300^{\circ} \mathrm{C}$. The results were converted to unit activity of platinum by the thermodynamic properties of the iron-platinum alloy formed. This allowed the mechanism of dissolution of platinum in the slag and the forms of platinum species in alumina-rich iron silicate slags in copper scrap smelting and refining conditions to be obtained. Our findings explain some inconsistent results in the geochemical literature by proposing an anionic dissolution mechanism at low oxygen partial pressures in iron-containing silicate slags.

\section{INTRODUCTION}

Recovery of platinum group elements (PGE) is difficult due to their low or very low concentrations. The question concerning which route various endof-life articles should take to be recycled for the recovery of their metal values is a key question for the circular economy of metals. Due to the significant complexity of modern electronic devices, their separation into simple monometallic fractions is virtually impossible, and the shredded and sorted material flows contain a complex mix of elements. The ultimate goal is recovery of as close as possible to $100 \%$ of these metals because they are rare, have unique properties and hence highly valuable. In this context, the chemical solubilities of, e.g., PGEs in smelting slags are very important. Only a few papers have dealt with platinum dissolution in metallurgical slags, but there is more information available in geological silicate systems.

\section{BACKGROUND INFORMATION}

Bennett et al. ${ }^{1}$ presented an analysis and summary of platinum solubility at $0.1 \mathrm{MPa}$ and high pressures in iron-free silicate melts at high temperatures, from 1800 to $2300^{\circ} \mathrm{C}$. Mann et al. ${ }^{2}$ assessed the metal-silicate distributions of several highly siderophile elements (HSE), and observed only a minor impact of pressure in the case of platinum. The reported concentrations of platinum at low oxygen pressures, e.g. Ertel et al. ${ }^{3,4}$ at $\mathrm{p}_{\mathrm{O} 2}<10^{-11.9}$ and $10^{-5} \mathrm{~atm}$, Amossé et al. ${ }^{5}$ at $\mathrm{p}_{\mathrm{O} 2}<10^{-6} \mathrm{~atm}$, have been assumed to be distorted by the presence of very small $(<100 \mathrm{~nm})$ metal inclusions, 'nanonuggets', as a result of an insufficient cooling rate. $1,6,7$

Different analytical techniques were used in measuring the solubility of platinum. Borisov and Palme $^{8}$ used neutron activation analysis, Dable et al. ${ }^{9}$ and Amossé et al. ${ }^{5}$ used chemical analysis after total dissolution, whereas Ertel et al., ${ }^{3,4}$ Bennett et al. ${ }^{1}$ as well as Malavergne et al. ${ }^{7}$ used in situ LA-ICP-MS (laser ablation-inductively coupled plasma-mass spectrometry) analysis. The quenching rates in the above studies varied from slow aircooling to direct quenching in water, with a duration from more than tens of minutes to a few seconds. It is considered that the in situ phase composition measurements generally provide a more accurate analysis of the chemically dissolved elements without errors from contamination and entrainments. 
Ertel et al. ${ }^{3,4}$ adopted a metal (80Pt20Rh) crucible for the silicate melt and sampling with an alumina dip-rod, quenched in water outside the furnace, in air. In their oxygen partial pressure series, the equilibration time between the points was several hundred hours, in spite of mechanical stirring of the melt during equilibration. This was due to the large (80-100 g) mass of the anorthite-diopside eutectic melt (50 wt. $\% \mathrm{SiO}_{2}, 23$ wt.\% $\mathrm{CaO}, 11$ wt.\% $\mathrm{MgO}$ and 15 wt. $\% \mathrm{Al}_{2} \mathrm{O}_{3}$ ) used. Bennett et al. ${ }^{1}$ used low-iron basalts with 4-9 wt.\% $\mathrm{FeO}$ in their $0.1 \mathrm{MPa}$ experiments, and Amossé et al. ${ }^{5}$ and Dable et al. ${ }^{9}$ highalumina calcium silicates.

The common conclusion of the oxidation degree of platinum in iron-free anorthite-diopside eutectic melts $\left(\mathrm{Pt}^{2+}\right.$ or $\mathrm{Pt}^{+}, \mathrm{PtO}$ or $\left.\mathrm{PtO}_{0.5}\right)$, as reported, e.g., by Borisov and Palme ${ }^{8}$ and Ertel et al., ${ }^{3,4}$ is that the observations are rather scattered, not only as a function of temperature ${ }^{2}$ but also as a function of oxygen activity. ${ }^{1}$ Farges et al., ${ }^{10}$ however, using a room-temperature XANES (x-ray absorption nearedge spectroscopy) technique proposed tetravalent $\mathrm{Pt}^{4+}\left(\mathrm{PtO}_{2}\right)$ as the predominant form of platinum in the iron-free, low- $\mathrm{SiO}_{2}$ (CAS or $\left.\mathrm{CaO}-\mathrm{Al}_{2} \mathrm{O}_{3}-\mathrm{SiO}_{2}\right)$ melts in air. A discrepancy has been discussed recently by Borisov and Danyushevsky ${ }^{11}$ and Borisov $^{12}$ who concluded tetravalent platinum was prevented, due to fast electron exchange during cooling,

$$
\mathrm{Pt}^{2+}=\mathrm{Pt}^{4+}+2 \mathrm{e}^{-}
$$

with other cations in the slag matrix. The discrepancy comes from the studies of Akai et al. ${ }^{13}$ who in their spectrometric measurements concluded that divalent platinum is the prevailing chemically dissolved species of platinum in melts equilibrated in air.

In metallurgical slags, the measurements on platinum distribution and solubility reported in the literature ${ }^{14-16}$ are on the high end of the available experimental values, probably due to errors in sampling and entrainment of metal or matte in the slag. Yamaguchi ${ }^{17}$ claimed that the concentration of platinum in metallurgical $\mathrm{FeO}_{x^{-}}$ $\mathrm{SiO}_{2}$ slags is a function of its copper concentration, which in isothermal, isobaric conditions and at constant oxygen activity is violating the Gibbs phase rule. However, a closer analysis of his data indicates the relationship arising from the activity of platinum in the alloy.

The thermodynamic properties of Fe-Pt alloys have been studied by several research teams. Larson and Chipman, ${ }^{18}$ Taylor and Muan, ${ }^{19}$ Heald, ${ }^{20}$ Petric et al., ${ }^{21,22}$ Gudmundsson and Holloway, ${ }^{23}$ Kessel et al. ${ }^{24}$ and Henao and Itagaki ${ }^{25}$ measured iron oxide-platinum equilibria in controlled oxygen partial pressures. Alcock and Kubik, ${ }^{26}$ Petric et al. ${ }^{21,22}$ and Fredriksson and Seetharaman ${ }^{27}$ used an emf technique with oxygen-conducting zirconia electrolytes for measuring the oxygen activity. The phase diagram measurements have been summarized by Nosé et al. ${ }^{28}$ and Okamoto. ${ }^{29}$ Fredriksson and Sundman and Fredriksson ${ }^{30,31}$ made a critical thermodynamic assessment of the system but they did not include recent geochemical data, e.g. Ref. 23, 24 in their study.

The aim of this study was to confirm the dissolution mechanism of platinum in iron-alumina spinelsaturated iron silicate slags and to measure the solubility of platinum at $1300^{\circ} \mathrm{C}$, as a function of oxygen partial pressure. This will allow us to verify the dissolution mechanism investigated earlier in copper-saturated slag systems of WEEE smelting (waste electric and electronic equipment) for dilute platinum concentrations. ${ }^{32-34}$

\section{EXPERIMENTAL}

The experimental technique employed involved sample equilibration at a controlled temperature, $1300^{\circ} \mathrm{C} \pm 3^{\circ} \mathrm{C}$, and in flowing gas atmosphere, followed by rapid quenching and direct elemental analyses of the equilibrium phases with EPMA (electron probe x-ray microanalysis) and LA-ICPMS.

The materials used in the experiments have been collected in Table I. The gas mixtures used to generate the different oxygen partial pressures at $1300^{\circ} \mathrm{C}$ were prepared using thermal mass flow controllers (DFC 26; Aalborg, USA) of different flow ranges, with an accuracy of $\pm 1 \%$ of the full range (Table II). The pure gas components were premixed at room temperature using an alumina pebble column. The chemically pure gases CO (99.97 vol.\%), $\mathrm{CO}_{2}$ (99.9992 vol.\%), and $\mathrm{Ar}$ (99.999 vol.\%) used were supplied by AGA-Linde (Finland). Argon was used to flush the work tube post-experiments. The raw materials were mixed and homogenized by grinding in an agate mortar with a metal-to-oxide ratio of $1: 9(\mathrm{w} / \mathrm{w})$ and a $\mathrm{Fe} / \mathrm{SiO}_{2}$ ratio of $1.3(\mathrm{w} / \mathrm{w})$ using pure substances as given in Table I.

The experimental apparatus and its gas train have previously been described in detail in the literature. ${ }^{35-37}$ Dense commercial alumina crucibles (AL23; Friatec, Germany) were used as the solid substrate to support the molten slag and solid platinum in the furnace.

The gas flow rates at room temperature used in the experiments have been collected in Table II. The prevailing partial pressures of oxygen given in the

Table I. The materials used in the experiments

\begin{tabular}{lcccc}
\hline Substance & & Purity (wt.\%) & & Supplier \\
\cline { 1 - 1 } $\mathrm{Al}_{2} \mathrm{O}_{3}$ crucible & & 99.5 & & Friatec, Germany \\
$\mathrm{Fe}_{2} \mathrm{O}_{3}$ powder & & 99.99 & & Alfa-Aesar, Germany \\
$\mathrm{Pt}$ powder & 99.98 & & Alfa-Aesar, Germany \\
$\mathrm{SiO}_{2}$ powder & & 99.99 & & Umicore, Germany \\
\hline
\end{tabular}


Table II. The gas mixtures and flow rates of the components used in the experiments

\begin{tabular}{lccc}
\hline $\log _{10} \mathbf{p}_{\mathbf{O} 2}(\mathbf{a t m})$ & $\mathbf{v}(\mathbf{C O})(\mathbf{m L} / \mathbf{m i n})$ & & $\mathbf{v}\left(\mathbf{C O}_{2}\right)(\mathbf{m L} / \mathbf{m i n})$ \\
\cline { 1 - 1 }$-5.0(0)$ & 1.3 & & 298.7 \\
$-6.0(1)$ & 4.1 & & 295.9 \\
$-7.0(1)$ & 12.6 & 287.4 \\
$-9.0(1)$ & 91.5 & & 208.5 \\
$-10.0(1)$ & 174.5 & & 125.6 \\
\hline
\end{tabular}

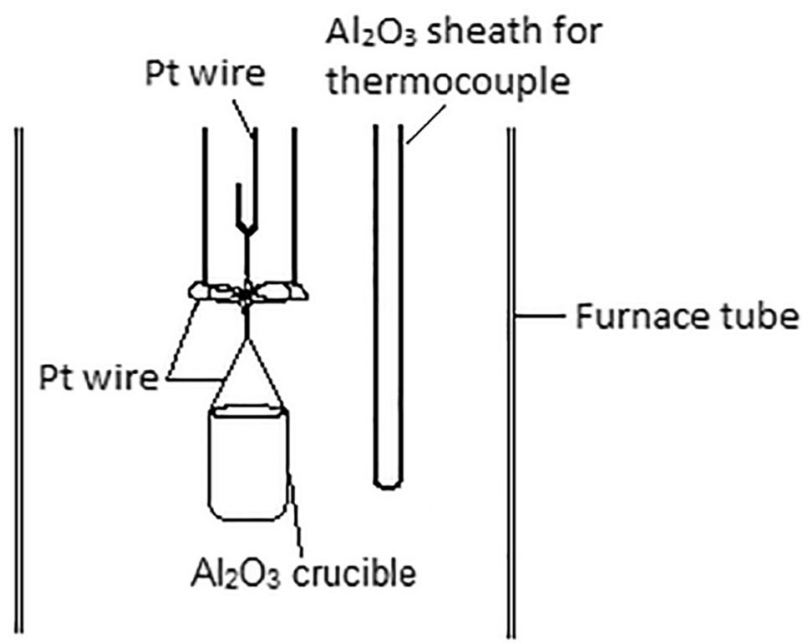

Fig. 1. Hot zone of the experimental furnace with measuring thermocouple next to the sample.

table were calculated from thermodynamic data of the SGTE pure substance database of the MTDATA software package. $^{38}$

The sample and the alumina crucible as sample holder in the hot zone of the experimental furnace are shown in Fig. 1. The mass of the alumina crucible (OD $10 \mathrm{~mm}$ ) was $1.7 \mathrm{~g}$ and the sample size used in the study was $0.18 \mathrm{~g}$ slag and $0.02 \mathrm{~g}$ metal, which ensured fast quenching in the ice-water bath. The sample was dropped into an ice-water mixture directly from the hot zone within the furnace work tube, and it cooled from the experimental conditions to room temperature in less than $5 \mathrm{~s}$.

To secure the time necessary for equilibrating the system and its phases, a series of experiments with durations of $16 \mathrm{~h}, 24 \mathrm{~h}$, and $48 \mathrm{~h}$ was conducted. In the pre-study, an identical starting composition and gas atmosphere were utilized, i.e., $\mathrm{CO}-\mathrm{CO}_{2}$ gas mixture producing an oxygen partial pressure of $10^{-9.0} \mathrm{~atm}$ at $1300^{\circ} \mathrm{C}$. No significant difference was observed in the elemental compositions of the slag and platinum alloy between $24 \mathrm{~h}$ and $48 \mathrm{~h}$. Nevertheless, to ensure the equilibrium was reached at all partial pressures, the experimental series was accomplished using the 48-h equilibration time. Two series of experimental runs were conducted in order to reliably measure the distribution coefficient of the platinum and the concentration of iron in the alloy as a function of the prevailing oxygen partial pressure.

After quenching, the samples were dried at room temperature and mounted in epoxy resin (EpoFix; Struers, Denmark). The polished sections, prepared by metallographic wet-polishing methods, were coated with carbon for SEM (scanning electron microscopy) and EPMA analyses using a Leica EM SCD050 sputter-coater (Leica Mikrosysteme, Austria). A Tescan Mira 3 SEM (Tescan, Brno, Czech Republic) was used for the surface quality and microstructure observations.

\section{EPMA}

The elemental compositions of quenched metal and slag were analyzed with a Cameca SX100 EPMA (Cameca, France) equipped with five wavelength dispersive spectrometers of which one spectrometer was used for oxygen analyses. The number of measurements in each phase was a minimum of eight. The beam diameters used were 1 and $100 \mu \mathrm{m}$ for the alloy/spinel and the slag, respectively. The beam focus size was based on the size of each phase area in the samples (see Fig. 2). The accelerating voltage and the beam current employed were $20 \mathrm{kV}$ and $60 \mathrm{nA}$, respectively.

The materials employed as external standards and the respective x-ray lines analyzed were pure natural minerals, i.e., $\mathrm{SiO}_{2}$ for $\mathrm{Si} \mathrm{K} \alpha, \mathrm{Fe}_{2} \mathrm{O}_{3}$ for $\mathrm{Fe}$ $\mathrm{K} \alpha$ and $\mathrm{O} \mathrm{K} \alpha, \mathrm{Al}_{2} \mathrm{O}_{3}$ for $\mathrm{Al} \mathrm{K} \alpha$, and $\mathrm{Fe}_{2} \mathrm{O}_{3}$ as well as pure Pt metal for Pt $\mathrm{L} \alpha$ in the alloy. Totals of the individual phase analysis after PAP-ZAF correction $^{39}$ varied between $97 \%$ and 99\%. Oxygen was removed from the alloy analyses as surface contamination.

\section{LA-ICP-MS}

The slag and spinel phases were examined with the LA-ICP-MS technique, since the concentrations of platinum were below the detection limit of EPMA. A Photon Machines Analyte Excite Laser Ablation System with 193-nm wavelength ArF excimer laser (Teledyne CETAC Technologies, USA) coupled to a $\mathrm{Nu}$ AttoM single collector sector field ICP-MS $(\mathrm{Nu}$ Instruments, UK) was employed for elemental analysis of the slag and spinel phases. The laser energy was set to $30 \%$ of $4.0 \mathrm{~mJ}$, resulting in a fluence of $1.98 \mathrm{~J} / \mathrm{cm}^{2}$ on the sample surface with an $85-\mu \mathrm{m}$ spot. The laser was operated at $10 \mathrm{~Hz}$ frequency starting with 5 pulses of pre-ablation for removal of the carbon coating and potential contamination from the surface, followed by 300 or 400 analysis pulses for the spinel and slag, respectively. The analyses were conducted in a low-resolution mode $(\Delta M / M=300)$ to maximize sensitivity. Spot sizes of $40 \mu \mathrm{m}$ were selected for the spinel analyses and $85 \mu \mathrm{m}$ for the slag. The number of identical composition measurements for the slag was a 

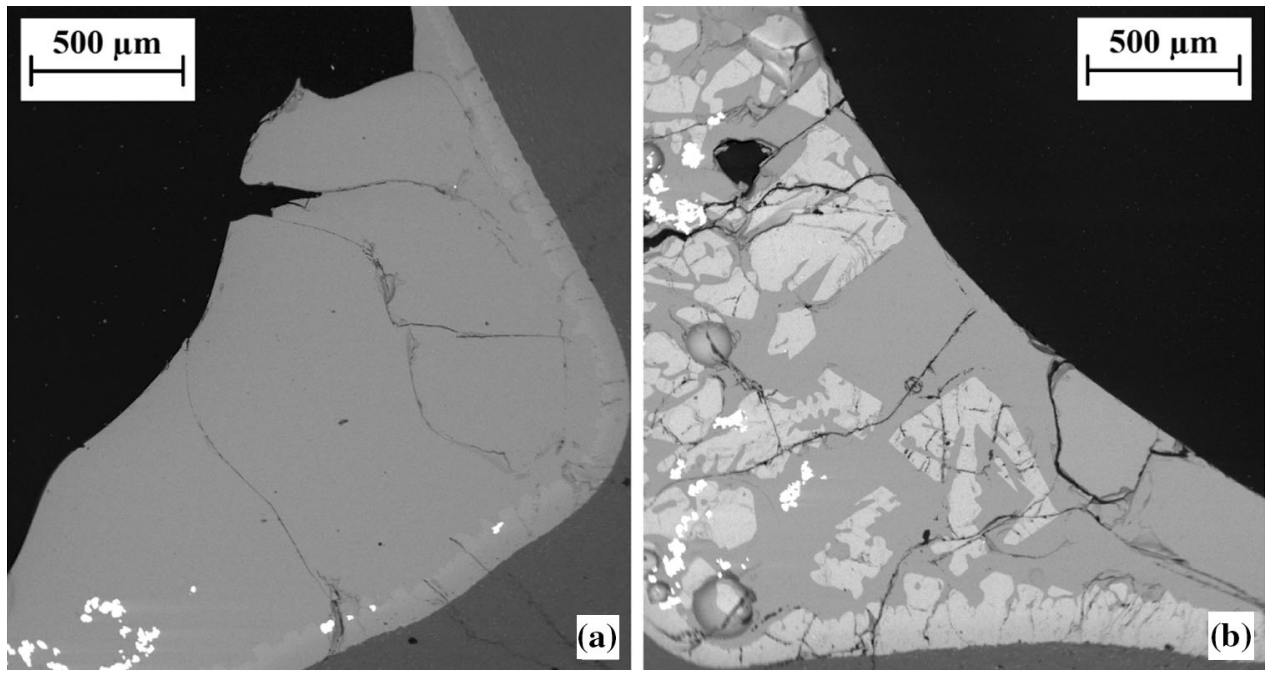

Fig. 2. SEM backscattered electron micrographs showing typical sample microstructures at oxygen partial pressures of $10^{-7}$ atm (a) and $10^{-5}$ atm (b). In reducing conditions, the spinel was only formed as a layer on the slag-crucible interface (a), whereas in oxidizing conditions $\left(\geq 10^{-6}\right.$ atm), larger individual spinel grains were also observed (b).

Table III. Detection limits of EPMA and LA-ICP-MS measurements for the alloy, spinel and slag (ppmw)

\begin{tabular}{|c|c|c|c|c|c|}
\hline Element phase & $\mathbf{O}$ & $\mathbf{A l}$ & $\mathbf{S i}$ & $\mathbf{F e}$ & $\mathbf{P t}$ \\
\hline EPMA & & & & & \\
\hline Slag & 1230 & 190 & 200 & 200 & 500 \\
\hline Spinel & 1060 & 180 & 130 & 190 & 500 \\
\hline $\begin{array}{l}\text { Pt-alloy } \\
\text { LA-ICP-MS }\end{array}$ & 1970 & 150 & 140 & 160 & 1800 \\
\hline Slag & & & & & $\begin{array}{l}{ }^{194} \mathrm{Pt}: 0.0015 \\
{ }^{195} \mathrm{Pt}: 0.0016 \\
{ }^{196} \mathrm{Pt}: 0.0019\end{array}$ \\
\hline Spinel & & & & & $\begin{array}{l}{ }^{194} \text { Pt: } 0.0080 \\
{ }^{195} \text { Pt: } 0.0080 \\
{ }^{196} \text { Pt: } 0.0090\end{array}$ \\
\hline
\end{tabular}

minimum of 8 , while it was $5-7$ for the spinel depending on the size of the spinel crystals.

For the slag analysis, NIST $612 \mathrm{SRM}^{40}$ was employed as the external standard and ${ }^{29} \mathrm{Si}$ as the internal standard. NIST 610, BHVO-2G and BCR-2G were analyzed as unknowns for monitoring the analysis accuracy. The Glitter software package $^{41}$ was applied for the raw data processing, i.e., the baseline reduction and quantifications.

The platinum concentrations with the LA-ICPMS technique were calculated using the averages of the ${ }^{194} \mathrm{Pt}$, ${ }^{195} \mathrm{Pt}$, and ${ }^{196} \mathrm{Pt}$ isotopes, with natural abundances of $32.864 \%, 33.775 \%$ and $25.211 \%$, respectively. ${ }^{42}$ The detection limits of both the analytical techniques employed in this study are summarized in Table III.

Only minor non-homogeneities in some timeresolved MS spectra were observed in the samples, as indicated by the uncertainties in Table IV. The time-resolved MS-signals were generally smooth as a function of time, and only occasional spikes were
Table IV. The primary data of alloy and slag concentrations at spinel saturation

\begin{tabular}{|c|c|c|c|}
\hline $\begin{array}{l}\text { Alloys } \\
\log _{10}\left(p_{02} / \text { atm }\right]\end{array}$ & Pt/wt.\% & $\mathrm{Fe} / \mathrm{wt} . \%$ & $\begin{array}{c}\text { Slag } \\
\text { Pt/ppbw }\end{array}$ \\
\hline \multirow[t]{2}{*}{-5.0} & $96.0 \pm 0.07$ & $4.0 \pm 0.06$ & $80.4 \pm 5.6$ \\
\hline & $95.4 \pm 0.1$ & $4.6 \pm 0.05$ & $77.4 \pm 6.6$ \\
\hline-6.0 & $92.6 \pm 0.2$ & $7.4 \pm 0.2$ & $54.8 \pm 4.5$ \\
\hline \multirow[t]{2}{*}{-7.0} & $90.1 \pm 0.1$ & $9.9 \pm 0.1$ & $32.5 \pm 5.2$ \\
\hline & $90.3 \pm 0.1$ & $9.7 \pm 0.08$ & $29.0 \pm 3.1$ \\
\hline \multirow[t]{2}{*}{-9.0} & $82.0 \pm 0.1$ & $18.0 \pm 0.08$ & $11.0 \pm 5.2$ \\
\hline & $81.9 \pm 0.1$ & $18.1 \pm 0.08$ & $8.4 \pm 3.4$ \\
\hline \multirow{2}{*}{-10.0} & $75.9 \pm 0.2$ & $24.1 \pm 0.04$ & $6.1 \pm 3.6$ \\
\hline & $74.9 \pm 0.1$ & $25.1 \pm 0.06$ & $5.7 \pm 3.1$ \\
\hline
\end{tabular}

present, as indicated in Fig. 3. This indicates that only a few nanonuggets of platinum were possibly present in the iron silicate slags prior to or after the quench. The quantification was, however, made by eliminating the large single channel spikes in the MS signals.

\section{RESULTS}

The EPMA data obtained for the Fe-Pt alloy and the platinum concentrations of the slag by LA-ICPMS are set out in Table IV. The LA-ICP-MS results for platinum in the slag and their experimental uncertainties $( \pm \sigma)$ were plotted graphically in Fig. 4. The uncertainty of the oxygen partial pressure, estimated from the accuracies of the thermal mass flow controllers, was $< \pm 0.2 \log$ units.

Figure 4 indicates that the concentration of platinum in alumina spinel-saturated iron silicate slags is very low, $80 \pm 6$ ppbw, even at the highest oxygen activities of copper-making conditions, around $\mathrm{p}_{\mathrm{O} 2}=$ $10^{-5} \mathrm{~atm}$ at $1300^{\circ} \mathrm{C}$. The concentration in the most 


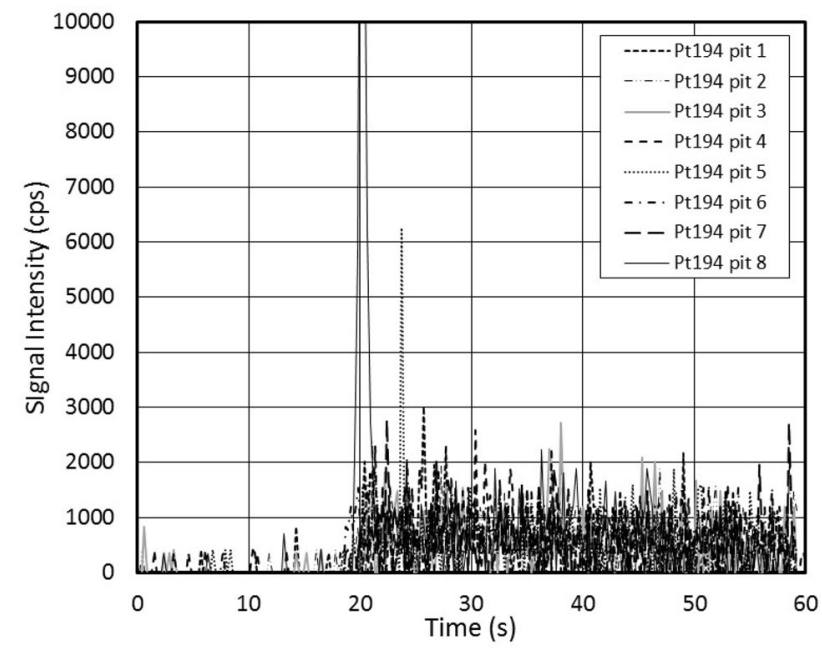

Fig. 3. A time-resolved analysis signal for platinum $\left({ }^{194} \mathrm{Pt}\right)$ of the $\mathrm{LA}$ ICP-MS measurements on the slag of a sample equilibrated at $10^{-5}$ atm oxygen partial pressure and $1300^{\circ} \mathrm{C}$; the ablation started approximately at $20 \mathrm{~s}$.

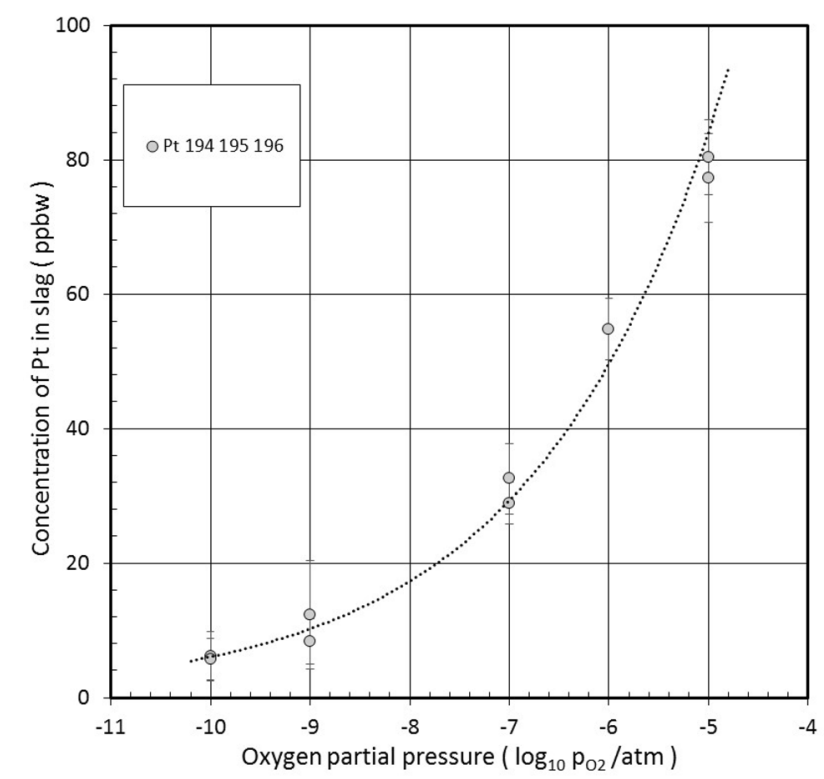

Fig. 4. The experimental concentrations of platinum in alumina spinel-saturated iron silicate slags as a function of the oxygen partial pressure at $1300^{\circ} \mathrm{C}$, as a mean value of three Pt isotopes.

reducing conditions of this study, $\mathrm{p}_{\mathrm{O} 2}=10^{-10} \mathrm{~atm}$, was also measured with good repeatability, and a value obtained was $6 \pm 3$ ppbw.

The composition of the platinum alloy particles was strongly affected by the prevailing oxygen partial pressure of the system due to iron dissolution in it during equilibration. The EPMA data of the solid alloy obtained is shown in Fig. 5. Using these data, the solubility of platinum $(* \mathrm{c}(\mathrm{Pt}))$, i.e., from pure metal and excluding the effects of dissolved iron from the slag, can be evaluated from the relationship:

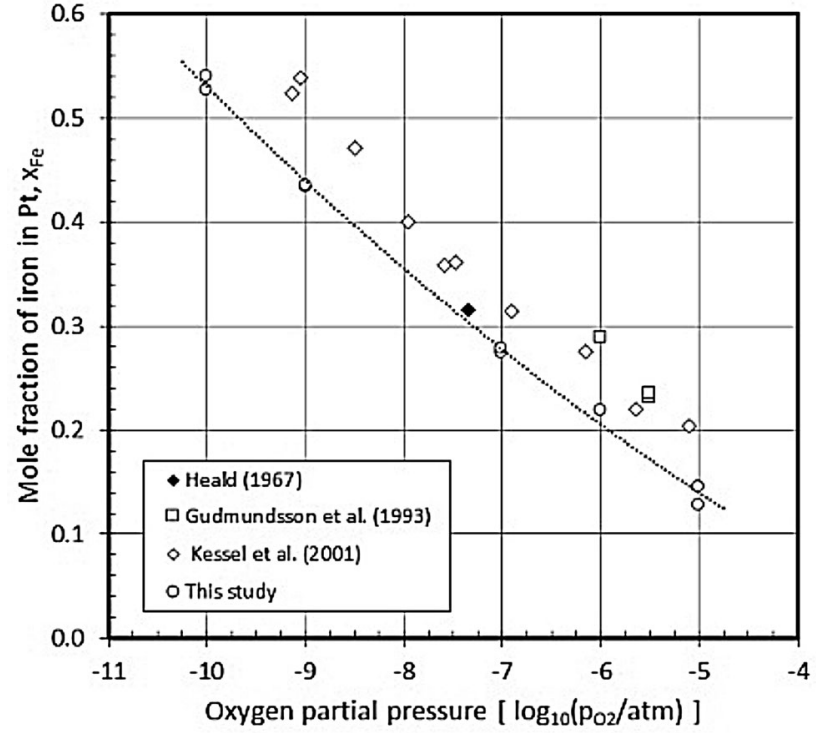

Fig. 5. Measured molar composition of the solid Pt-Fe alloy at different oxygen partial pressures in equilibrium with alumina spinelsaturated iron silicate slags at $1300^{\circ} \mathrm{C}$; the literature data refer to selected pure iron oxide-platinum equilibrium measurements.

$$
* c(\mathrm{Pt})=c(\mathrm{Pt}) / a[\mathrm{Pt}]
$$

where $a[\mathrm{Pt}]$ is the activity of platinum in the metallic Fe-Pt alloy, referred to as the pure solid platinum, and $c(\mathrm{Pt})$ is the measured concentration of platinum in the slag at that activity.

The activity of iron in the silicate slag can be estimated based on the iron solubility in the alloy, once the activity versus composition relationship of the Fe-Pt system is known, as a result of the general equilibrium property of heterogeneous systems:

$$
\mu_{\text {alloy }}(\mathrm{Fe})=\mu_{\text {slag }}(\mathrm{Fe}) .
$$

The apparent distribution coefficient of platinum between the metal alloy and molten slag was defined as:

$$
L^{\mathrm{m} / \mathrm{s}}(\mathrm{Pt}) \equiv[\mathrm{wt}-\% \mathrm{Pt}]_{\text {alloy }} /(\mathrm{wt}-\% \mathrm{Pt})_{\text {slag }}
$$

where $[\% \mathrm{Pt}]_{\text {alloy }}$ and $(\% \mathrm{Pt})_{\text {slag }}$ are the measured concentrations of platinum in the phases. The functional relationship between $\mathrm{L}$ and the oxygen partial pressure can be obtained using the dissolution reaction of platinum in the slag, which can be written as

$$
[\mathrm{Pt}]_{\text {alloy }}+\mathrm{n} / 2 \mathrm{O}_{2}(\mathrm{~g})=\left(\mathrm{PtO}_{\mathrm{n}}\right)_{\text {slag }}
$$

where $n$ refers to the oxidation degree of the forming platinum oxide $(-2 \times n)$ in the molten slag. The dissolving platinum in Eq. 5 was written as an alloy, due to the dissolution of iron from the slag. Using the equilibrium constant of Eq. (5) and organising logarithmic form of Eq. (3), we obtain: 


$$
\begin{aligned}
\log ^{\prime} L^{\mathrm{m} / \mathrm{s}}(\mathrm{Pt})= & \log L^{\mathrm{m} / \mathrm{s}}(\mathrm{Pt})+\log \left\{f[\mathrm{Pt}] / n^{T}[\text { alloy }]\right\} \\
= & \log \left[1 / \mathrm{K} \cdot f\left(\mathrm{PtO}_{n}\right) / n^{T}(\mathrm{slag})\right]-n / 2 \\
& \cdot \log \mathrm{p}_{\mathrm{O} 2}
\end{aligned}
$$

where ' $L^{\mathrm{m} / \mathrm{s}}(\mathrm{Pt})$ is called the thermodynamic distribution coefficient and $L^{\mathrm{m} / \mathrm{s}}(\mathrm{Pt})$ is the apparent distribution coefficient (see Fig. 6). In this case, the composition of the platinum alloy, the activity coefficient of platinum, and the number of moles in the alloy $n^{T}$ [alloy] vary so significantly that they must be taken into account when calculating the oxygen activity slope of the metal-slag distribution coefficient. In Eq. (6), the symbols $n^{T}$ (slag) and $n^{T}$ [alloy] refer to the numbers of moles in $100 \mathrm{~g}$ slag and alloy, respectively, $\mathrm{K}$ is the equilibrium constant of reaction (5), and $f\left(\mathrm{PtO}_{n}\right)$ and $f[\mathrm{Pt}]$ are the Raoultian activity coefficients of platinum oxide in the slag and platinum in the solid alloy, respectively. The treatment is similar to that used earlier, e.g., by Bennett et al., ${ }^{1}$ Mann et al., ${ }^{2}$ Médart et al. ${ }^{6}$ and Fortenfant et al. ${ }^{43}$ Equation (2) can be easily converted to Eq. (6) as ' $L$ m/s $(\mathrm{Pt})=100 / * w(\mathrm{Pt})$, where ${ }^{*} w$ (Pt) is the solubility of platinum in the slag as weight fraction.

The standard state of metallic platinum is solid, pure platinum, and that of platinum oxide $\mathrm{PtO}$ may be either solid or liquid oxide, due to the fact that its solubility never reaches values beyond very dilute solutions. Thus, the thermodynamic distribution coefficients of platinum between iron-platinum alloy and molten iron silicate slag, ' $L^{\mathrm{m} / \mathrm{s}}(\mathrm{Pt})$, were obtained by plotting the second member of Eq. (6) as a function of $\log \mathrm{p}_{\mathrm{O} 2}$ (see Fig. 7). The error bars of the distribution coefficients given in Fig. 6 were estimated from the experimental uncertainties $(1 \sigma)$ of the EPMA and LA-ICP-MS data, as proposed earlier by Strengell et al. ${ }^{44}$

The activity coefficients of platinum in ironplatinum alloys, used for the evaluation of Eq. (6), were obtained from the assessment of Kessel et al. ${ }^{24}$ They were based on their experimental iron activity data of a wide concentration range in platinum-rich alloys $\left(x_{P \mathrm{t}}>0.5\right)$ at $1200-1400^{\circ} \mathrm{C}$. Their experimental data are in good agreement with Gudmundsson and Holloway ${ }^{23}$ (see Fig. 4), but show slightly lower activity coefficients of iron at $1300^{\circ} \mathrm{C}$ than Petric et al. ${ }^{21}$ and Fredriksson. ${ }^{31}$ The data of Larson and Chipman, ${ }^{18}$ Taylor and Muan, ${ }^{19}$ Heald ${ }^{20}$ and Alcock and Kubik ${ }^{26}$ were also rather scattered and deviate systematically from recent observations.

The behavior of the metal-to-slag (thermodynamic) distribution coefficient in the experimental range of this study is shown in Fig. 7. Its oxygen partial pressure dependency forms a maximum at around $\log _{10} \mathrm{p}_{\mathrm{O} 2}=-7$, suggesting the iron silicate slag dissolution of platinum as an anionic species at low oxygen pressures and as a cationic species at high oxygen partial pressures. We can assume that the oxidation degree of platinum in iron-bearing

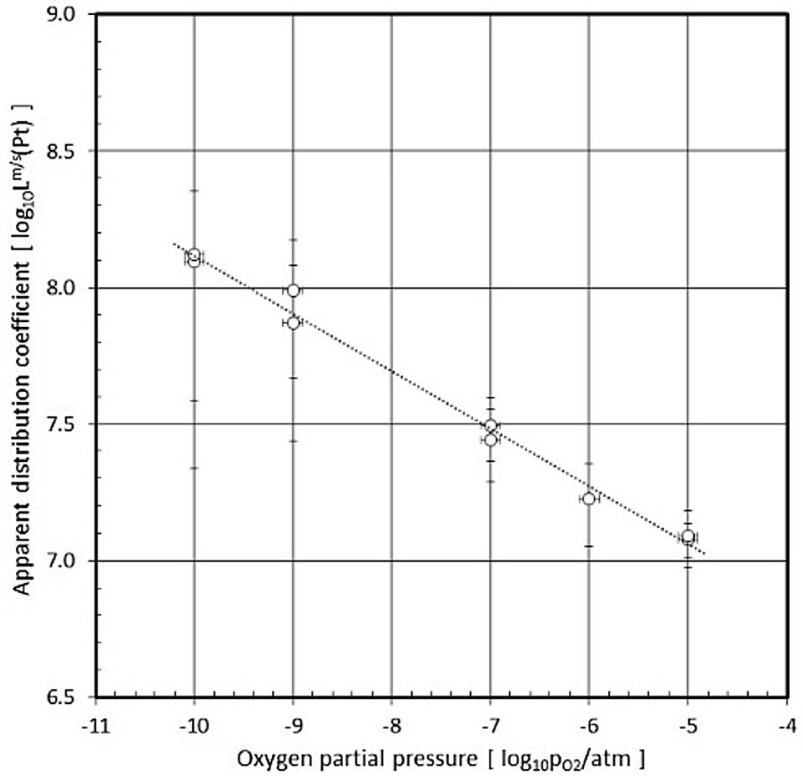

Fig. 6. The apparent distribution coefficient of platinum between FePt alloys and alumina spinel-saturated iron silicate slag as a function oxygen partial pressure obtained in the present study.

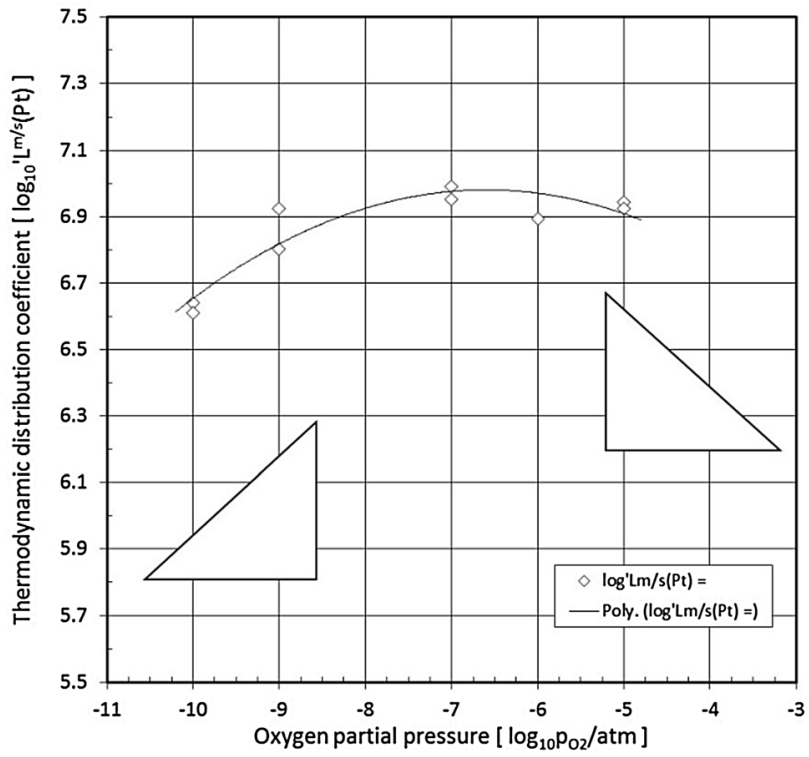

Fig. 7. The thermodynamic distribution coefficient of platinum between metal and slag as a function of oxygen partial pressure; the triangles represent the slopes of $+1 / 4$ and $-1 / 4$.

slags at high oxygen partial pressures is the same as in iron-free or low-iron silicate slags, ${ }^{1,2,4,7}$ and thus the dissolution mechanism and its reaction can be written as:

$$
[\mathrm{Pt}]+1 / 4 \mathrm{O}_{2}(\mathrm{~g})=\left(\mathrm{PtO}_{0.5}\right) .
$$

The oxide species $\mathrm{PtO}_{0.5}$ (or $\mathrm{Pt}_{2} \mathrm{O}$ ) is not a stable form of platinum oxides. In reducing conditions, the slope refers to an anionic dissolution mechanism of platinum and can be written as: 


$$
1 / 2(\mathrm{FeO})+[\mathrm{Pt}]=1 / 2\left(\mathrm{FePt}_{2}\right)+1 / 4 \mathrm{O}_{2}(\mathrm{~g})
$$

in the case where the intermetallic platinum species that forms is the platinum-rich member of the Fe-Pt alloy system. ${ }^{30}$ Thus, both dissolution mechanisms result in a $\log { }^{\prime} L^{\mathrm{m} / \mathrm{s}}(\mathrm{Pt})$ versus $\log \mathrm{p}_{\mathrm{O} 2}$ slopes of $1 / 4$ but with different signs, and the solubility of platinum in iron-bearing silicate slags has a minimum value. The oxygen partial pressure range of this study does not allow accurate determination of the slopes due to the relative narrow stability range of molten iron silicate slags at $1300^{\circ} \mathrm{C}$, i.e., slightly below $10^{-10}$ atm, the slag will be saturated by metallic iron, while above $10^{-5}$ atm, it decomposes to solid silica and solid magnetite.

The distribution coefficient of platinum between the molten slag and solid iron alumina spinel was measured at a few points only, due to the small crystal size of the spinel precipitates in the slag matrix. The measurements at $\mathrm{p}_{\mathrm{O} 2}=10^{-5}-10^{-6} \mathrm{~atm}$ gave an average value of $L^{\mathrm{s} / \mathrm{sp}}(\mathrm{Pt})=3 \pm 1.5$ for the slag-to-spinel distribution coefficient of platinum.

\section{DISCUSSION AND CONCLUSION}

The measured concentration of platinum in alumina spinel-saturated iron silicate slags in equilibrium with pure metallic platinum at $1300^{\circ} \mathrm{C}$ was very low, in general $<0.1 \mathrm{ppmw}$ in the copper smelting and refining conditions, which greatly favors the pyrometallurgical route for PGE recycling. In reducing conditions, close to the saturation of the slags by solid iron, the concentration decreased towards values close to the limits of current analytical methods. In this study, in contact with FePt alloys, the apparent solubility of $6 \pm 3$ ppbw was obtained at $\mathrm{p}_{\mathrm{O} 2}=10^{-10} \mathrm{~atm}$. The estimated solubility of platinum in the slag, when eliminating the effects of dissolved iron on the activity of platinum in the solid alloy, at oxygen partial pressures of $10^{-5}-10^{-6}$ atm was $120 \pm 10$ ppbw. This is in good agreement with the geochemical data on acidic silicate slags and glasses. $^{4,8}$

It is well known in the literature that multivalent elements, such as sulfur or tellurium, may exist as cationic and anionic species in silicate and other melts, depending on the prevailing oxygen partial pressure, e.g. Ref. 45, 46. The slag matrix also affects the dissolution mechanism of cations at constant oxygen activity, as shown by Nakamura et al., ${ }^{47}$ who, in the case of platinum, proposed anionic and cationic dissolution mechanisms when the slag basicity was adjusted from low-silica to high-silica. In this study, the predominant form of platinum in the slag apparently was the $\mathrm{Pt}^{+}$ion, or a $\mathrm{PtO}_{0.5}$ oxide species, above about $10^{-7}$ atm oxygen partial pressure, and an intermetallic species, $\mathrm{FePt}_{2}$, in more reducing conditions. The present observations on the high-oxygen partial pressure side are in good agreement with the previous results from iron-free basalt (anorthite-diopside eutectic) melts. ${ }^{4,8}$ Also, the data by Ertel et al. ${ }^{4}$ and Bennett et al. ${ }^{1}$ on platinum solubilities at low oxygen pressures support the anionic dissolution mechanism of platinum, even if the presented dissolution mechanisms were different. On the other hand, Amossé et al. ${ }^{5}$ and Dable et al. ${ }^{9}$ found a minimum in the platinum solubility, concluding it to be a consequence of dissolution as a neutral platinum species. This study indicated that such a minimum in reducing conditions can be caused by anionic dissolution as a $\mathrm{FePt}_{2}$ intermetallic species in ironcontaining silicate melts.

As shown experimentally by, e.g., Nakamura et al. $^{47}$ and Borisov and Danyushevskij, ${ }^{11}$ silica concentration or the slag basicity have a great influence on the solubility and dissolution mechanisms of platinum and several other elements in molten silicates. In general, low-silica compositions dissolve orders of magnitude higher concentrations of PGEs compared with the slags close to silica saturation. This is also supported by the tendency of platinum to form stable double oxides with alkaline earth metals. ${ }^{48}$

It is, therefore, evident that, in the oxidising process steps, platinum also dissolves as $\mathrm{PtO}_{0.5}$ in copper-containing iron silicate slags used in secondary copper smelting and refining. Thus, the recent experimentally determined concentrations of platinum in metallurgical slags, ${ }^{33,34,36}$ as well as the relationships obtained for platinum distributions between the copper and the slag, were distorted by the detection limits of the analytical techniques used in the phase analyses, as considered earlier. ${ }^{34}$ In addition, the chemical dissolution of platinum in the slag in this study is lower than stated in our recent papers, ${ }^{34,36}$ where concentrations were reported as upper limits only. However, the role of anionic dissolution mechanisms at low oxygen partial pressures in iron-bearing slags limits platinum solubility in the slag to about $0.1 \mathrm{ppmw}$. The observed behavior of platinum may have direct consequences for the geochemistry of HSE species, see, e.g., Fortenfant et al. ${ }^{43}$ and Mann et al. ${ }^{2}$ It also suggests that chemically dissolving platinum concentration in sulfide smelting slags is very low, and even in platinum concentrate smelting with 1000 ppm PGEs in the matte, ${ }^{49}$ platinum concentration in the slag is below $<1$ ppbw, as shown earlier. $^{50,51}$

\section{ACKNOWLEDGMENTS}

Open access funding provided by Aalto University. The study was enabled by financial support of CMEco (Grant \# 7405/31/2016) and SYMMET (Grant \# 3891/31/2018) programs of Business Finland, which are gratefully acknowledged. The additional support from the Steel and Metals Producers' Fund (LK), Alfred Kordelin Foundation, Finnish Cultural Foundation as well as Emil Aal- 
tonen Foundation (KA) is also appreciated. The EPMA measurements were carried out by Mr Lassi Pakkanen of Geological Survey of Finland. This study utilised the Academy of Finland's RawMatTERS Finland Infrastructure (RAMI) housed at Aalto University, GTK and VTT.

\section{OPEN ACCESS}

This article is licensed under a Creative Commons Attribution 4.0 International License, which permits use, sharing, adaptation, distribution and reproduction in any medium or format, as long as you give appropriate credit to the original author(s) and the source, provide a link to the Creative Commons licence, and indicate if changes were made. The images or other third party material in this article are included in the article's Creative Commons licence, unless indicated otherwise in a credit line to the material. If material is not included in the article's Creative Commons licence and your intended use is not permitted by statutory regulation or exceeds the permitted use, you will need to obtain permission directly from the copyright holder. To view a copy of this licence, visit http://creativecommons.org/licenses/by/4.0/.

\section{REFERENCES}

1. N.R. Bennett, J.M. Brenan, and K.T. Koga, Geochim. Cosmochim. Acta 133, 422 (2014).

2. U. Mann, D.J. Frost, D.C. Rubie, H. Becker, and A. Audietat, Geochim. Cosmochim. Acta 84, 593 (2012).

3. W. Ertel, D.B. Dingwell, and P.J. Sylvester, Chem. Geol. 248, 119 (2008)

4. W. Ertel, H.S.C. O'Neill, P.J. Sylvester, and D.B. Dingwell, Geochim. Cosmochim. Acta 63, 2439 (1999).

5. J. Amossé, P. Dable, and M. Allibert, Mineral. Petrol. 68, 29 (2000).

6. E. Médard, M.W. Schmidt, M. Wälle, N.S. Keller, and D. Günther, Geochim. Cosmochim. Acta 162, 183 (2015).

7. V. Malavergne, E. Charon, J. Jones, P. Cordier, K. Righter, D. Deldicque, and L. Hennet, Earth Planet. Sci. Lett. 434, 197 (2016)

8. A. Borisov and H. Palme, Geochim. Cosmochim. Acta 61, 4349 (1997).

9. P. Dable, M. Allibert, and J.C. Poignet, J. Am. Ceram. Soc. 84, 1097 (2001).

10. F. Farges, D.R. Neuville, and E.B. Brown Jr, Am. Mineral. 84,1562 (1999).

11. A. Borisov and L. Danyushevsky, Eur. J. Mineral. 23, 355 (2011).

12. A.A. Borisov, Petrology 24, 117 (2016).

13. T. Akai, J. Nishii, M. Yamashita, and H. Yamanaka, J. NonCyst. Solids 222, 304 (1997).

14. H.M. Henao, K. Yamaguchi, and S. Ueda, Sohn International Symposium, Vol. 1, ed. F. Kongoli and R.G. Reddy (Warrendale, PA: TMS, 2006), pp. 723-729.

15. K. Baba and K. Yamaguchi, J. MMIJ 129, 208 (2013).

16. S. Nakamura and N. Sano, Metall. Mater. Trans. B 28B, 103 (1997).

17. K. Yamaguchi, Proceedings of Copper 2010, Vol. 1 (Clausthal-Zellerfeld: GDMB, 2010), pp. 1287-1295.

18. H.R. Larson and J. Chipman, Acta Metall. 2 , 1 (1954).

19. R.W. Taylor and A. Muan, Trans. AIME 224, 500 (1962).

20. E.F. Heald, Trans. AIME 239, 1337 (1967).
21. A. Petric, K.T. Jacob, and C.B. Alcock, J. Am. Ceram. Soc. 64, 632 (1981).

22. A. Petric and K.T. Jacob, J. Am. Ceram. Soc. 65, 117 (1982).

23. G. Gudmundsson and J.R. Holloway, Am. Mineral. 78, 178 (1993).

24. R. Kessel, J.R. Beckett, and E.M. Stolper, Am. Mineral. 86, 1003 (2001).

25. H.M. Henao and K. Itagaki, Metall. Mater. Trans. B 38B, 769 (2007).

26. C.B. Alcock and A. Kubik, Acta Metall. 17, 437 (1969).

27. P. Fredriksson and S. Seetharaman, Scand. J. Metall. 30, 258 (2001).

28. Y. Nosé, A. Kushida, T. Ikeda, H. Nakajima, K. Tanaka, and H. Numakura, Mater. Trans. 44, 2723 (2003).

29. H. Okamoto, J. Phase Diagr. Differ. 25, 395 (2004).

30. P. Fredriksson and B. Sundman, Calphad 25, 535 (2001).

31. P. Fredriksson, Ph.D. thesis, Royal University of Technology, Stockholm, 2003.

32. K. Avarmaa, H. O'Brien, H. Johto, and P. Taskinen, J. Sustain. Metall. 1, 216 (2015).

33. D. Sukhomlinov and P. Taskinen, Proceedings of EMC 2017, Vol. 3 (Clausthal-Zellerfeld: GDMB, 2017), pp. 1029-1938.

34. K. Avarmaa, L. Klemettinen, H. O'Brien, and P. Taskinen, Miner. Eng. 133, 95 (2019).

35. N. Hellstén, J. Hamuyuni, and P. Taskinen, Can. Metall. Q. 55,226 (2016)

36. K. Avarmaa, H. Johto, and P. Taskinen, Metall. Mater. Trans. B 47B, 244 (2016).

37. L. Klemettinen, K. Avarmaa, H. O'Brien, P. Taskinen, and A. Jokilaakso, Minerals 9, 39 (2019).

38. R.H. Davies, A.T. Dinsdale, J.A. Gisby, J.A.J. Robinson, and S.M. Martin, CALPHAD 26, 229 (2002).

39. J.L. Pouchou, F. Pichoir, 11th International Congress on Xray Optics and Microanalysis (ICXOM), eds. by J.D. Brown, R.H. Packwood. (Ontario, Canada: University of Ontario, 1986), pp. 249-256.

40. K.P. Jochum, U. Weis, B. Stoll, D. Kuzmin, Q. Yang, I. Raczek, D.E. Jacob, A. Stracke, K. Birbaum, D.A. Frick, D. Günther, and J. Enzweiler, Geostand. Geoanal. Res. 35, 397 (2011).

41. E. van Achterberg, C. Ryan, S. Jackson, W. Griffin, Laser Ablation ICP-MS in the Earth Science. Short Course Series \#29 (St John, Newfoundland: Mineralogical Association of Canada, 2001), pp. 239-243.

42. IUPAC Periodic Table of Elements and Isotopes; accessed on March 27, 2019 at https://www.isotopesmatter.com/applets/ IPTEI/IPTEI.html.

43. S.S. Fortenfant, D. Günther, D.B. Dingwell, and D.C. Rubie, Geochim. Cosmochim. Acta 67, 123 (2003).

44. D. Strengell, K. Avarmaa, H. Johto, and P. Taskinen, Can. Metall. Q. 55, 234 (2016).

45. P.J. Jugo, R.W. Luth, and J.P. Richards, Geochim. Cosmochim. Acta 69, 497 (2005).

46. I.V.K. Kojo, P. Taskinen, and K.R. Lilius, Metall. Trans. B 16B, 171 (1985).

47. S. Nakamura, K. Iwasawa, K. Morita, and N. Sano, Metall. Mater. Trans. B 29B, 411 (1998).

48. T. Jacob, T.H. Okabe, T. Uda, and Y. Waseda, Z. Metallkde 90, 491 (1999).

49. R.H. Eric, J. SA IMM 103, 499 (2004)

50. P. Piskunen, K. Avarmaa, H. O'Brien, L. Klemettinen, and P. Taskinen, Metall. Mater. Trans. B 49B, 98 (2018).

51. K. Avarmaa, H. O'Brien, P. Taskinen, in 10th International Conference on Molten Slags, Fluxes and Salts, eds. R. Reddy, P. Chaubal, P.C. Pistorius, U. Pal. (Warrendale: Wiley/ TMS, 2016), CD-ROM, pp. 193-202.

Publisher's Note Springer Nature remains neutral with regard to jurisdictional claims in published maps and institutional affiliations. 